\title{
Dry Washing in Biodiesel Purification: a Comparative Study of Adsorbents
}

\author{
Candice Schmitt Faccini, ${ }^{a}$ Michele Espinosa da Cunha, ${ }^{a}$ Maria Silvana Aranda Moraes, ${ }^{a}$ \\ Laiza C. Krause, ${ }^{a}$ Márcia C. Manique, ${ }^{b}$ Maria Regina A. Rodrigues, ${ }^{c}$ \\ Edilson V. Benvenutti ${ }^{a}$ and Elina B. Caramão ${ }^{*, a, d}$
}

\author{
${ }^{a}$ Curso de Pós Graduação em Química and ${ }^{b}$ Programa de Pós Graduação em Ciência dos Materiais, \\ Instituto de Química, Universidade Federal do Rio Grande do Sul, Porto Alegre-RS, Brazil \\ 'Departamento de Química Orgânica, Instituto de Química, Universidade Federal de Pelotas, \\ Pelotas-RS, Brazil
}

${ }^{d} I N C T$ E\&A, Instituto Nacional de Ciência e Tecnologia em Energia e Ambiente, Centro Interdisciplinar de Energia e Ambiente (CIEnAm), Campus Universitário de Ondina, 40170-115 Salvador-BA, Brazil

\begin{abstract}
O objetivo deste trabalho é comparar a eficiência de diferentes adsorventes na purificação de biodiesel produzido por transesterificação alcalina do óleo de soja (metanol/KOH). As metodologias propostas foram baseadas na utilização de Magnesol $^{\circledR}$, sílica, Amberlite BD10 DRY ${ }^{\circledR}$ e Purolite PD $206^{\circledR}$ como adsorventes e foram desenvolvidas por adsorção a $65^{\circ} \mathrm{C}$. A eficiência de cada adsorvente foi medida através do teor residual de potássio, álcool, água e sabão, dissolvidos no biodiesel purificado. Como resultado, observamos que Magnesol $^{\circledR}$ e sílica apresentaram melhores propriedades de adsorção que Amberlite BD10 DRY®e Purolite PD 206 ${ }^{\circledR}$, especialmente para remover sabão, glicerina livre e ligada e potássio. Em comparação com a lavagem ácida convencional, estas matrizes foram consideradas adequadas para a remoção de espécies contaminantes inorgânicas e orgânicas do biodiesel. Os principais resultados encontrados para estes dois adsorventes (Magnesol ${ }^{\circledR} 1 \%$ e sílica 2\%) foram valores abaixo de $0,17 \mathrm{mg} \mathrm{KOH} \mathrm{g}^{-1}$ de acidez, $1 \mathrm{mg} \mathrm{kg}^{-1}$ de potássio, 61 ppm de sabão, $500 \mathrm{mg} \mathrm{kg}^{-1}$ de água, 0,22\% de metanol, 0,30\% de glicerina livre e $0,03 \%$ de glicerina ligada.
\end{abstract}

The purpose of this work is to compare the efficiency of different adsorbents in the purification of biodiesel produced by alkaline transesterification of soybean oil (Methanol/KOH). The proposed methodologies were based on the use of Magnesol ${ }^{\circledR}$, silica, Amberlite BD10 DRY ${ }^{\circledR}$ and Purolite PD $206^{\circledR}$ as adsorbents and were developed by adsorption at $65^{\circ} \mathrm{C}$. The response of each adsorbent was measured through the residual potassium, alcohol, water and soaps dissolved in the purified biodiesel. As a result, we observe that Magnesol ${ }^{\circledR}$ and silica showed better adsorption properties than Amberlite BD10 DRY ${ }^{\circledR}$ and Purolite PD $206^{\circledR}$, especially for removing soap, free and bonded glycerol and potassium. In comparison to the conventional acid water washing, these matrices were found to be equally appropriate for the removal of inorganic and organic contaminant species from biodiesel. The main results found for these two adsorbents (Magnesol ${ }^{\circledR} 1 \%$ and silica $2 \%$ ) were values below $0.17 \mathrm{mg} \mathrm{KOH} \mathrm{g}^{-1}$ for acid number, $1 \mathrm{mg} \mathrm{kg}^{-1}$ of $\mathrm{K}, 61 \mathrm{ppm}$ of soap, $500 \mathrm{mg} \mathrm{kg}^{-1}$ of water, $0.22 \%$ of methanol and $0.03 \%$ of free glycerol.

Keywords: biodiesel, dry wash, Magnesol ${ }^{\circledR}$, silica, Amberlite $^{\circledR}$, Purolite $^{\circledR}$

\section{Introduction}

Biodiesel is a diesel fuel substitute obtained mainly by basic catalytic transesterification of oils and fats, and

\footnotetext{
*e-mail: elina@ufrgs.br
}

it is composed by fatty acid mono-alkyl esters that are produced from the reaction of low-acid-number vegetable oils with an alcohol in the presence of a basic catalyst. ${ }^{1-3}$ Biodiesel is currently produced by the base-catalyzed transmethylation of triglycerides, producing fatty acids methyl esters (FAME). ${ }^{4,5}$ At the end of the reaction, the 
glycerol rich-phase is separated from the methyl ester layer by decantation.

Methyl esters usually contain contaminant materials that are detrimental to the quality of the fuel, and must be eliminated from the product. Removal of glycerol and glycerides from biodiesel is an important step of the process because key aspects of the quality of the fuel strongly depend on the content of free and bound glycerol. ${ }^{1}$ Although it is slightly soluble in biodiesel, glycerol can be found dispersed as small droplets in biodiesel. ${ }^{6,7}$ High concentrations of glycerol in biodiesel can cause problems during storage due to its separation, and in usage by forming deposits on injection nozzles and promoting an increase in aldehyde emissions. ${ }^{7}$ The presence of water in the biodiesel can cause engine corrosion or side reactions with glycerides to produce soaps and glycerol. ${ }^{8}$ Soaps and free fatty acids cause the deterioration of certain components of engines. Thus, the determination of the water amount and free fatty acid are essential for the viability of biodiesel use and also for the choice of the raw materials (vegetable oil or animal fat) employed in the transesterification process. Sodium and potassium contamination in biodiesel can be caused by the use of catalysts in biodiesel production $(\mathrm{KOH}$ or $\mathrm{NaOH}$ ). Both of these ions can cause the formation of insoluble soaps, which can be deposited in the motor and also promote catalytic polymerization reactions. ${ }^{9-11}$

Reduction of the water-soluble contaminants is traditionally accomplished by water washing of the biodiesel. However, the water-wash method results in an aqueous effluent, which can then cause a detrimental environmental impact. ${ }^{12}$ Many processes have been developed ${ }^{8,13-15}$ using hot water-washing in the purification of biodiesel, but these studies demonstrate the disadvantage of using large amounts of water, generating effluent. This large amount of effluent can reach at least $3 \mathrm{~g}$ of water per gram of biodiesel. ${ }^{16}$

The conventional "wet" methods of purification involving water-washing can be replaced by "dry" purification with adsorbents or ion exchange resins. ${ }^{13,17}$ Moreover, the solid residue obtained by this purification has to be disposed of to landfill or other applications (compost, potential animal feed additive and potential fuel). ${ }^{15}$

The inorganic matrix Magnesol ${ }^{\circledR}$ is a synthetic adsorbent composed of magnesium silicate and anhydrous sodium sulfate. It can be used to remove contaminants such as water, soap, free glycerol and glycerides from biodiesel. ${ }^{1,13,15}$ Yori et al. ${ }^{1}$ and Predojevic ${ }^{8}$ studied the removal of glycerol from biodiesel from waste frying oils with elevated acid values using silica and achieved high purity of the resultant biodiesel. ${ }^{1,8}$

The organic resin Amberlite BD10 DRY ${ }^{\circledR}$ is already being used in pilot industries, where biodiesel is purified through a column filled with the resin. ${ }^{18}$ Another ion exchange resin commonly employed is Purolite PD $206^{\circledR}$, which is a selective special organic resin that has been developed to remove maximum amounts of waste water, soaps, salts, catalysts and glycerol during the biodiesel purification process. ${ }^{19}$ Both resins were also studied by Berrios and Skelton, ${ }^{15}$ who investigated these ion exchange resins by passing the feed through a column of resin supported in a glass tube at room temperature.

The present study aimed to investigate the use of inorganic matrices (Magnesol ${ }^{\circledR}$ and silica) and organic resins (Amberlite BD10 DRY ${ }^{\circledR}$ and Purolite PD 206 ${ }^{\circledR}$ ) as adsorbents in the biodiesel purification process and to compare this dry purification process with the conventional wet purification process (acid water washing).

\section{Materials and Methods}

\section{Materials}

Solvents and other reagents were of Merck p.a. grade (for analysis) or equivalent. The chromatographic standards of fatty acids methyl esters (FAMEs) were purchased from Supelco (Bellefonte, USA). The gases used in the chromatographic analyses $\left(\mathrm{H}_{2}, \mathrm{~N}_{2}, \mathrm{He}\right.$ and synthetic air with purity greater than $99 \%$ ) were purchased from White Martins. Magnesol ${ }^{\circledR}$ (particle size diameter: $60 \mu \mathrm{m}$ ) was obtained from Dallas Group of America, Inc. (Jefferson City, MO, 122 USA), Amberlite BD10 DRY ${ }^{\circledR}$ (particle size diameter: $900 \mu \mathrm{m}$ ) and Purolite PD $206^{\circledR}$ (particle size diameter: $600 \mu \mathrm{m}$ ) were provided by Rohm and Haas Chemical Ltd., and silica from Merck. It was not possible, for reasons of commercial confidentially, to obtain any information on the chemical composition of the resins. Edible soybean oil was purchased in a local market from Liza ${ }^{\circledR}$, with high degree of purity (acid number $=0.05 \mathrm{mg} \mathrm{KOH} \mathrm{g}^{-1}$ ).

\section{Biodiesel synthesis by a transesterification reaction}

Soybean oil was weighed into a $1000 \mathrm{~mL}$ threeneck reactor adapted to a water bath with a temperature controller. The reactor (FGG Equipment and Glasses Laboratory Ltd.) was assembled with a condenser and an adjustable speed mechanical stirrer (Fisatom model 710) fixed at $300 \mathrm{rpm}$. The reactor was heated to $65{ }^{\circ} \mathrm{C}$ by circulation of hot water. In the meantime, $1.5 \%$ of $\mathrm{KOH}$, considering the weight basis of soybean oil, was dissolved in methanol, and the mixture added to the reactor in a $6: 1$ molar ratio (in relation to the mass of oil). The overall mixture was maintained at $65^{\circ} \mathrm{C}$ during the reaction. After $30 \mathrm{~min}$, the heating and stirring were stopped, and the 
mixture was removed from the bottom of the reactor. The reaction mixture was transferred to a separatory funnel to promote the separation of the glycerol and biodiesel phases. The glycerol phase was recovered after phase separation, carrying most of the dissolved catalyst with it. The upper layer, containing the desired product not yet purified, was removed to a beaker and heated at $90{ }^{\circ} \mathrm{C}$ for $10 \mathrm{~min}$ to evaporate the excess of methanol. The unpurified biodiesel was divided in five portions and each of them was submitted to different purification processes.

\section{Wet purification process}

The unpurified biodiesel was washed thoroughly with $10 \%$ acid water (related to the total volume of biodiesel not purified that is, $1 / 5$ of total volume of biodiesel produced in the reaction) at $55^{\circ} \mathrm{C}$. The acid water was prepared by adding $2 \%(\mathrm{v} / \mathrm{v})$ phosphoric acid $\left(\mathrm{H}_{3} \mathrm{PO}_{4}\right.$ p.a. Merck) to distilled water. This washing step was performed in the same transesterification reactor with constant stirring over $5 \mathrm{~min}$, maintaining the temperature at $55^{\circ} \mathrm{C}$. Afterwards, the mixture was transferred to a separatory funnel and the waste water and biodiesel phases were separated. The bottom layer (waste water) was removed and the biodiesel was washed three times with portions of $10 \%(\mathrm{v} / \mathrm{v})$ hot water $\left(55^{\circ} \mathrm{C}\right)$. The upper layer, containing the purified biodiesel, was stored for further analysis.

\section{Dry purification process}

The dry purification conditions were based on the literature, ${ }^{15}$ the unpurified biodiesel was heated and stirred slowly until reaching $65{ }^{\circ} \mathrm{C}$. At this point, $1 \%$ or $2 \%$ $(\mathrm{m} / \mathrm{m})$ of each adsorbent (Magnesol ${ }^{\circledR}$, silica, Amberlite BD10 DRY ${ }^{\circledR}$ and Purolite PD $206^{\circledR}$ ), related to the mass of biodiesel, was added maintained $65{ }^{\circ} \mathrm{C}$ and stirring for $20 \mathrm{~min}$. The biodiesel was then filtered to remove the adsorbent and stored for further analysis.

\section{Analysis of biodiesel}

Samples of purified and unpurified biodiesel were analyzed by their acid number, potassium, soap, water and residual methanol content. Because of economical reasons, the analysis of glycerol and glycerides was only done for biodiesel not purified, purified with acid water and purified with the two better adsorbents, in the better conditions. The acid number analysis was performed according to European standard EN 14104 and the potassium content with EN 14109 using atomic absorption spectrometer AAS Vario 6 (Analytik Jena). The soap and catalyst content were determined with the method AOCS CC 17-19 and water content by the coulometric Karl Fischer method, based on EN ISO 12937. The determination of glycerol and glycerides was performed according to ASTM Method D-6584 using GC/FID (Shimadzu GC-2010, with auto sampler AOC-20i). The methanol determination was performed according to European standard EN 14110 by using GC/FID (Shimadzu GC-17A).

$\mathrm{N}_{2}$ adsorption-desorption isotherms of the adsorbents

$\mathrm{N}_{2}$ adsorption-desorption isotherms were obtained at the $\mathrm{N}_{2}$ boiling point temperature in a homemade volumetric apparatus connected to a turbo molecular Edwards vacuum line system, employing an $\mathrm{Hg}$ capillary barometer. Silica and Magnesol ${ }^{\circledR}$ were previously degassed at $140{ }^{\circ} \mathrm{C}$, under vacuum, for $2 \mathrm{~h}$. The specific area and pore size distribution were estimated by the BET (Brunauer, Emmett and Teller) and the BJH (Barret, Joyner and Hallenda) methods, respectively. ${ }^{20,21}$

\section{Scanning electron microscopy (SEM)}

The silica and Magnesol ${ }^{\circledR}$ materials were analyzed by scanning electron microscopy in a Jeol microscope; model JSM 5800. Images were recorded at a range of magnification between 100 and $12000 \times$.

\section{Results and Discussion}

\section{Characterization of inorganic matrices}

Inorganic matrices, such silica and Magnesol ${ }^{\circledR}$, show interesting properties, such as high chemical and thermal stability and structural rigidity that prevent leaching and avoid swelling, which properties allow their use as selective and reusable adsorbents. ${ }^{22-24}$

The textural characteristics of the silica and Magnesol ${ }^{\circledR}$ were investigated using $\mathrm{N}_{2}$ isotherms, which are presented in Figure 1. The Magnesol ${ }^{\circledR}$ adsorption curve is a typical "type I" isotherm, characteristic of microporous materials, where the main adsorption occurs at low relative $\mathrm{P} / \mathrm{P}_{0}$ pressures. $^{25,26}$ The silica isotherms present a different behavior, with a major adsorption for $\mathrm{P} / \mathrm{P}_{0}$ higher than 0.5 . This curve is a typical "type IV" isotherm, characteristic of mesoporous materials. ${ }^{25,26}$ The pore size distribution curves are showed in Figure 2, where it is possible to observe that the silica matrix presents a large amount of mesopores compared with Magnesol ${ }^{\circledR}$. The specific surfaces were similar, with 400 and $470 \pm 20 \mathrm{~m}^{2} \mathrm{~g}^{-1}$ for silica and Magnesol $^{\circledR}$, respectively. 


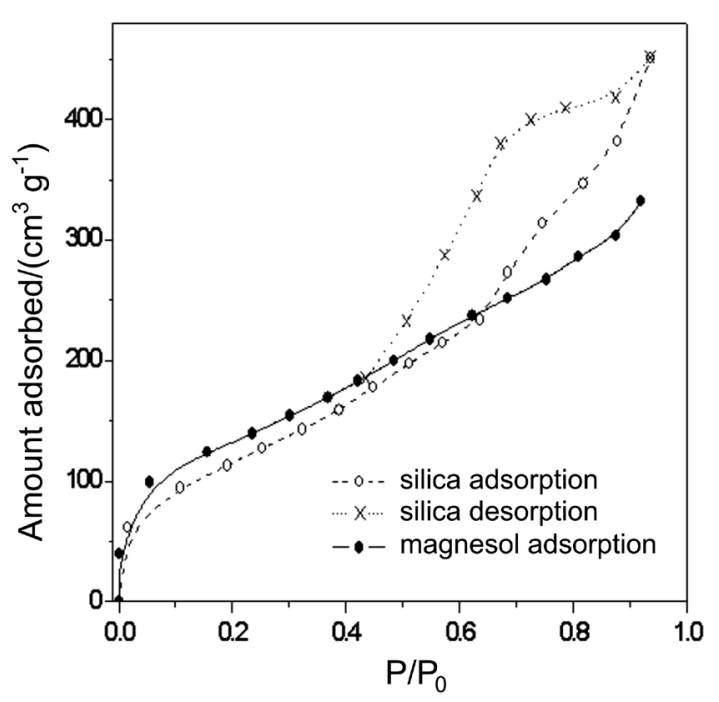

Figure 1. $\mathrm{N}_{2}$ adsorption-desorption curves.

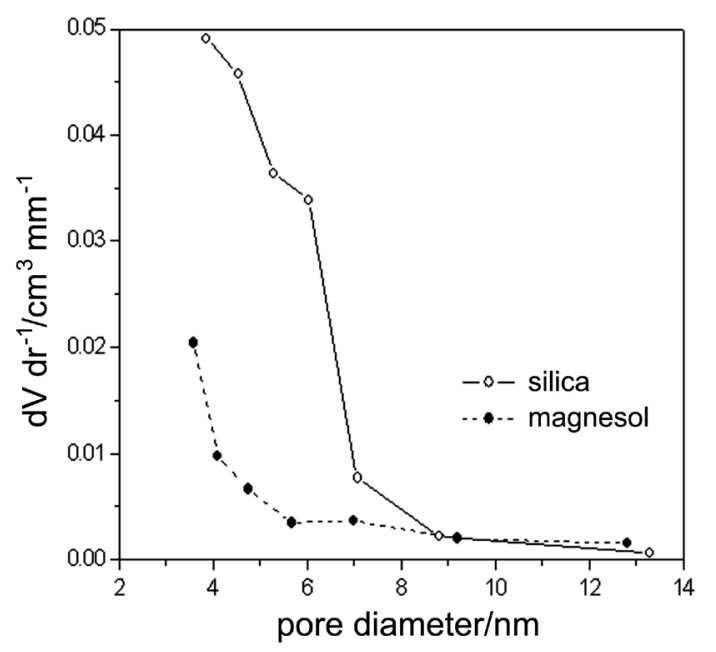

Figure 2. Pore size distribution curves.

The SEM images are included in Figure 3. The Magnesol ${ }^{\circledR}$ material presents spherical particles with diameters between 10 and $50 \mu \mathrm{m}$, while silica particles are larger than $100 \mu \mathrm{m}$. With the images obtained under high magnification, however, it is possible to observe a macroporous structure, which is not present in the silica image.

Although the specific surfaces for both inorganic matrices were similar, silica was predominately a mesoporous material (pore diameter between 2 and $50 \mathrm{~nm}$ ), while the Magnesol ${ }^{\circledR}$ was predominately a microporous (diameter lower than $2 \mathrm{~nm}$ ) and macroporous (larger than $50 \mathrm{~nm}$ ) material.

\section{Biodiesel purification}

The results of analysis of acid number, potassium, soap, water and residual methanol of purified and unpurified biodiesel samples are presented in Table 1 . These analyses

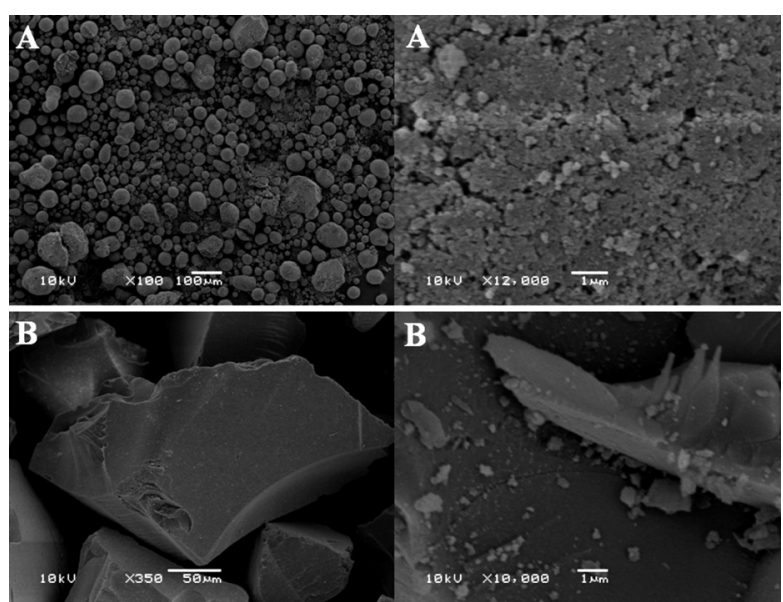

Figure 3. SEM images of (A) Magnesol ${ }^{\circledR}$ and (B) silica matrices.

were done in triplicate. All the samples showed values of acid number within the specification of biodiesel, where the specification limit for acid number from Resolution 07/2008 from ANP, National Petroleum Agency, Brazil (Agência Nacional de Petróleo, Gás Natural e Biocombustíveis) is $0.50 \mathrm{mg} \mathrm{KOH} \mathrm{g}^{-1}$. Although legislation does not define the limit of soap contamination in biodiesel for commercial use, this contaminant can be present in transesterification reactions and can cause damage in motors. It can be observed from the Table 1 data, the inorganic matrices silica and $\mathrm{Magnesol}^{\circledR}$ were more efficient in soap removal. The obtained values for soap for inorganic matrices purified biodiesel were significantly lower than those found for organic resins or acid water washing. Considering the observed water content, the values present in the samples after biodiesel purification, again demonstrated that the inorganic matrices showed the best results.

The maximum methanol percentage acceptable in biodiesel is $0.2 \%$ and, according to the data, only samples purified by acid water washing and with Magnesol $^{\circledR}(1 \%)$ showed values within specification. According to Berrios et al. ${ }^{15}$ methanol must be removed by flash chromatography separation or a similar process.

In regards to the amount of potassium, which is also an undesirable contaminant, inorganic matrices present satisfactory results with values below the specification limit for potassium defined in Resolution 07/2008 from ANP at $5 \mathrm{mg} \mathrm{kg}^{-1}$.

Considering all these results, the inorganic matrices Magnesol ${ }^{\circledR}$ and silica showed the best performance in biodiesel purification for removing mainly organic species, such as soap. Therefore, the biodiesel samples purified by these matrices (Magnesol ${ }^{\circledR} 1 \%$ and silica $2 \%$ ) were selected for further analysis of other undesirable organic contaminants, specifically free and bonded glycerol. These selected samples were compared with unpurified biodiesel 
Table 1. Main properties of unpurified and purified biodiesel $(n=3)$

\begin{tabular}{|c|c|c|c|c|c|}
\hline Samples & $\begin{array}{c}\text { Acid Number } \\
\text { (mg KOH/g) }\end{array}$ & $\begin{array}{l}\text { Soap } \\
(\mathrm{ppm})\end{array}$ & $\begin{array}{c}\mathrm{K} \\
(\mathrm{mg} / \mathrm{kg}) \\
\end{array}$ & $\begin{array}{c}\text { Water } \\
(\mathrm{mg} / \mathrm{kg})\end{array}$ & $\begin{array}{c}\text { Methanol } \\
(\%)\end{array}$ \\
\hline Not purified & $0.33 \pm 0.01$ & $1670.05 \pm 7.30$ & $23.2 \pm 0.2$ & $1300 \pm 15$ & $2.13 \pm 0.10$ \\
\hline Acid water washing & $0.22 \pm 0.01$ & $158.12 \pm 3.01$ & $19.9 \pm 1.6$ & $1400 \pm 15$ & $0.18 \pm 0.01$ \\
\hline Magnesol ${ }^{\circledR} 1 \%$ & $0.17 \pm 0.01$ & $60.84 \pm 2.10$ & $1.1 \pm 0.1$ & $500 \pm 6$ & $0.19 \pm 0.10$ \\
\hline Magnesol $^{\circledR} 2 \%$ & $0.16 \pm 0.01$ & $60.85 \pm 2.10$ & $1.2 \pm 0.1$ & $800 \pm 7$ & $0.33 \pm 0.10$ \\
\hline Silica $1 \%$ & $0.15 \pm 0.01$ & $60.81 \pm 2.34$ & $\operatorname{tr}$ & $700 \pm 6$ & $0.21 \pm 0.01$ \\
\hline Silica $2 \%$ & $0.14 \pm 0.01$ & $60.80 \pm 2.50$ & $\operatorname{tr}$ & $500 \pm 5$ & $0.22 \pm 0.10$ \\
\hline Amberlite $^{\circledR} 1 \%$ & $0.16 \pm 0.01$ & $152.03 \pm 4.30$ & $16.7 \pm 1.2$ & $1000 \pm 12$ & $0.30 \pm 0.10$ \\
\hline Amberlite ${ }^{\circledR} 2 \%$ & $0.14 \pm 0.01$ & $182.62 \pm 5.03$ & $2.6 \pm 0.3$ & $900 \pm 9$ & $0.39 \pm 0.01$ \\
\hline Purolite $^{\circledR} 1 \%$ & $0.15 \pm 0.02$ & $212.87 \pm 5.3$ & $10.5 \pm 1.5$ & $1200 \pm 12$ & $0.44 \pm 0.10$ \\
\hline Purolite $^{\circledR} 2 \%$ & $0.21 \pm 0.01$ & $243.33 \pm 2.7$ & $\operatorname{tr}$ & $1100 \pm 10$ & $0.59 \pm 0.01$ \\
\hline EN 14214 maximum & 0.50 & - & 5.0 & $500 \pm 5$ & 0.20 \\
\hline
\end{tabular}

$\operatorname{tr}=$ traces

Table 2. Results of the analysis of bonded and free glycerol for unpurified and purified biodiesel

\begin{tabular}{lccccc}
\hline & $\begin{array}{c}\text { Unpurified } \\
\text { Biodiesel }\end{array}$ & Purified Biodiesel & & EN 14214 \\
\cline { 3 - 5 } & & Acid water washing & Magnesol $^{\circledast}$ 1\% & Silica 2\% & maximum \\
\hline Total glycerol (\%) & 0.71 & 0.36 & 0.28 & 0.30 & 0.25 \\
Free glycerol (\%) & 0.26 & 0.01 & 0.02 & 0.03 & 0.02 \\
Monoglycerides (\%) & 0.14 & 0.15 & 0.09 & 0.10 & - \\
Diglycerides (\%) & 0.12 & 0.07 & 0.06 & 0.07 & - \\
Triglycerides (\%) & 0.19 & 0.13 & 0.11 & 0.10 & - \\
\hline
\end{tabular}

and also with biodiesel purified by acid water washing. The results of these analyses are shown in Table 2. These data were not obtained in triplicate. It can be seen that the inorganic matrices, Magnesol ${ }^{\circledR}$ and silica, also showed suitable results for free and bonded glycerol removal. These results were comparable with acid water washing.

\section{Conclusions}

The main advantages of using dry purifications are the drastic reduction of aqueous effluents, making the process environmentally friendly, and the substantial reduction in the total time of production, since water washing requires the use of two cycles of washing and one stage of centrifugation, which are time intensive processes. The inorganic matrices Magnesol ${ }^{\circledR}$ and silica were successfully applied as adsorbents for biodiesel purification. These matrices were appropriated for removal of both inorganic and organic species. The results obtained using inorganic matrices were better than using organic resins. The performance of the inorganic matrices seems to not be influenced by the textural characteristics, like pore and particle size. The main reason for the difference in performance could be considered as a result of the chemical characteristic of the inorganic matrices, which present a more rigid and crosslinked structure.

\section{Acknowledgments}

The authors would like to acknowledge the assistance and support given by CNPq (Conselho Nacional de Pesquisa e Desenvolvimento) and Megapetro Petróleo Brasil Ltda.

\section{References}

1. Yori, J. C.; D’Ippolito, S. A.; Pieck, C. L.; Vera, C. R.; Energy Fuels 2007, 21, 347.

2. Moraes, M. S. A.; Krause, L. C.; da Cunha, M. E.; Faccini, C. S.; de Menezes, E. W.; Veses, R. C.; Rodrigues, M. R. A.; Caramão, E. B.; Energy Fuels 2008, 22, 1949.

3. da Cunha, M. E.; Krause, L. C.; Moraes, M. S. A.; Faccini, C. S.; Jacques, R. A.; Almeida S. R.; Rodrigues, M. R. A.; Caramão, E. B.; Fuel Process. Technol. 2009, 90, 570.

4. Mahajan, S.; Konar, S. K.; Boocock, D. G. B.; JAOCS 2007, 84, 189. 
5. Barnwal, B. K.; Sharma, M. P.; Renew. Sust. Energy Rev. 2005, 9, 363 .

6. Bondioli, P.; Bella, L. D.; Eur. J. Lipid Sci. Technol. 2005, 107, 153.

7. Mittelbach, M.; Bioresour. Technol. 1996, 56, 7.

8. Predojevic, Z. J.; Fuel 2008, 87, 3522.

9. Hajimahmoodi, M.; Heyden, Y. V.; Sadeghi, N.; Jannat, B.; Oveisi, M. R.; Shahbazian, S.; Talanta 2005, 66, 1108.

10. Joshi, R. M.; Pegg, M. J.; Fuel 2007, 86, 143.

11. Zhou, W. Y.; Boocock, D. G. B.; JAOCS 2006, 83, 1041.

12. Bryan, T.; Biodiesel Magazine (march 2005) available in http:// www.biodieselmagazine.com accessed in September, 2010.

13. Kucek, K. T.; César-Oliveira, M. A. T.; Wilhelm, M. H.; Ramos, L.; JAOCS 2007, 84, 385.

14. Glisic, S. B.; Skala, D. U.; Chem. Ind. Chem. Eng. Q. 2009, 15, 159.

15. Berrios, M.; Skelton, R. L.; Chem. Eng. J. 2008, 144, 459.

16. Cooke, B. S.; Abrams, C.; Bertram, B.; US Patent 0509959P 2003.

17. Karaosmanoglu, F.; Cigizoglu, K. B.; Tuter, M.; Ertekin, S.; Energy Fuels 1996, 10, 890.
18. http//www.biodiesel.gov.br/docs/congressso2006/producao/ plantapiloto31.pdf accessed in September 2010.

19. http//www.ecopress.org.br accessed in September 2010.

20. Sing, K. S. W.; Everett, D. H.; Haul, R. A. W.; Moscou, L.; Pierotti, R. A.; Rouquérol, J.; Siemieniewska, T.; Pure Appl. Chem. 1985, 57, 603.

21. Chandrasekhar, S.; Pramada, P. N.; J. Int. Adsorp. Soc. 2006, 12, 27.

22. Farag, R. S.; Basuny, A. M. M.; Int. J. Food Sci. Technol. 2009, 44, 1802.

23. Bhattacharya, A. B.; Sajilata, M. G.; Tiwari, S. R.; Singhal, R. S.; Food Chem. 2008, 110, 562.

24. Farag, R. S.; Basuny, A. M. M.; Arafat, S. M.; Arafa, S. A.; Int. J. Food Sci. Technol. 2009, 44, 1850.

25. Sing, K. S. W.; Adv. Colloid Interface Sci. 1998, 76, 3.

26. Benvenutti, E. V.; Moro, C. C.; Costa, T. M. H.; Gallas, M. R.; Quim. Nova 2009, 32, 1926.

Submitted: April 21, 2010

Published online: November 16, 2010 